\title{
Lysobacter ruishenii sp. nov., a chlorothalonil- degrading bacterium isolated from a long-term chlorothalonil-contaminated soil
}

\author{
Guang-Li Wang,† Li Wang,† Hong-Hong Chen, Bin Shen, Shun-Peng Li \\ and Jian-Dong Jiang
}

Correspondence

Jian-Dong Jiang

jiang_jjd@njau.edu.cn

\begin{abstract}
Department of Microbiology, Key Laboratory of Microbiological Engineering of Agricultural Environment, Ministry of Agriculture, College of Life Sciences, Nanjing Agricultural University, 210095, Nanjing, Jiangsu, PR China
\end{abstract}

The genus Lysobacter, grouped in the family Xanthomonadaceae, is classified in the class Gammaproteobacteria (Christensen \& Cook, 1978) based on non-fruiting bodies, lack of flagella, gliding nature and high genomic DNA $\mathrm{G}+\mathrm{C}$ content (typically ranging between 65.4 and $70.1 \mathrm{~mol} \%$ ) (Aslam et al., 2009). Species of the genus Lysobacter have been described as ubiquitous inhabitants of soil and water, and are commonly found in diverse geographical and environmental habitats (Romanenko et al., 2008; Yassin et al., 2007). At the time of writing, the genus Lysobacter comprises 16 recognized species, four described since 2009 (Aslam et al., 2009; Srinivasan et al., 2010; Ten et al., 2009; Wang et al., 2009). Members of the

TThese authors contributed equally to this work.

The GenBank/EMBL/DDBJ accession number for the $16 \mathrm{~S}$ rRNA gene sequence of strain $\mathrm{CTN}-1^{\top}$ is GU086401.

Three supplementary figures and a supplementary table are available with the online version of this paper. genus were found to have great potential for the development of biocontrol agents against plant fungal pathogens (Islam et al., 2005; Park et al., 2008) and antibiotic compounds against human pathogens (Ahmed et al., 2003; Hashizume et al., 2004). However, to the best of our knowledge, members of the genus Lysobacter with the ability to degrade xenobiotics have not been reported.

Chlorothalonil (2,4,5,6-tetrachloroisophthalonitrile), a broad-spectrum chlorinated aromatic fungicide, is the second most widely used agricultural fungicide in the United States, with $5 \times 10^{6} \mathrm{~kg}$ applied annually (Cox, 1997). Chlorothalonil is highly toxic to fish, birds and aquatic invertebrates (Caux et al., 1996) and is commonly detected in ecosystems (Kazos et al., 2008). During the isolation of chlorothalonil-degrading micro-organisms, a bacterial strain (designated CTN-1 ${ }^{\mathrm{T}}$ ) capable of efficiently degrading chlorothalonil without the presence of other carbon sources was characterized from a long-term chlorothalonil-contaminated soil at the Jiangyin Suli Chemical Co., Ltd 
(Jiangsu, China). Strain $\mathrm{CTN}-1^{\mathrm{T}}$ was characterized by a polyphasic approach, including determination of chemotaxonomic and phenotypic properties, phylogenetic analysis based on 16S rRNA gene sequences and genomic relatedness. On the basis of the results obtained, we propose that strain $\mathrm{CTN}-1^{\mathrm{T}}$ should be placed in the genus Lysobacter as the type strain of a novel species.

The isolation of strain $\mathrm{CTN}-1^{\mathrm{T}}$ was carried out by enrichment culture with minimal salt medium (per litre distilled water: $1.0 \mathrm{~g} \quad \mathrm{NH}_{4} \mathrm{NO}_{3}, \quad 1.5 \mathrm{~g} \mathrm{~K}_{2} \mathrm{HPO}_{4}, \quad 0.5 \mathrm{~g}$ $\mathrm{KH}_{2} \mathrm{PO}_{4}, 0.2 \mathrm{~g} \mathrm{MgSO}_{4}$ and $1.0 \mathrm{~g} \mathrm{NaCl}, \mathrm{pH} 7.0$ ) supplemented with $50 \mathrm{mg}$ chlorothalonil $\mathrm{l}^{-1}$. Chlorothalonil (99.3\% purity) was purchased from Sigma-Aldrich. The enrichment culture was spread on Luria-Bertani (LB) agar (Difco) containing $100 \mathrm{mg}$ chlorothalonil $\mathrm{l}^{-1}$. Colonies with clear transparent zones due to chlorothalonil degradation were selected and purified.

For investigation of morphological and physiological characteristics, strain $\mathrm{CTN}^{-1}{ }^{\mathrm{T}}$ was cultivated on $\mathrm{LB}$ medium at $30{ }^{\circ} \mathrm{C}$. Cell morphology and motility were examined by light microscopy (Olympus; $\times 1000$ ) and transmission electron microscopy (H-7650; Hitachi) by using cells from an exponentially growing culture. Gramstaining was performed by using the non-staining method described by Buck (1982). The physiological properties of strain $\mathrm{CTN}^{-1}{ }^{\mathrm{T}}$ were determined by using previously described tests for hydrolysis of casein, aesculin, gelatin, starch and urea (Brown, 2007), hippurate (Kinyon \& Harris, 1979), elastin (Ohman et al., 1980), guanine and adenine (Wallace et al., 1995), cellulose (Ten et al., 2004) and Tween 20 (Atlas, 1993). Catalase activity was determined with $3 \%(\mathrm{v} / \mathrm{v}) \mathrm{H}_{2} \mathrm{O}_{2}$, and oxidase activity was determined by using $1 \%(\mathrm{w} / \mathrm{v})$ tetramethyl-p-phenylenediamine. Enzyme activity and acid production from different carbohydrates were determined by using API ZYM, API $50 \mathrm{CH}$, API $20 \mathrm{NE}$ and API ID $32 \mathrm{GN}$ kits according to the manufacturer's instructions (bioMérieux). API ZYM strips were read after $5 \mathrm{~h}$ of incubation. The assimilation of single carbon substrates was determined by using API ID $32 \mathrm{GN}$ and API 20NE strips cultured at $30{ }^{\circ} \mathrm{C}$ for $24 \mathrm{~h}$. Growth at $4,10,15,25,30,37,42$ and $45{ }^{\circ} \mathrm{C}$ and at $\mathrm{pH} 4.0-10.0$ (at intervals of $1.0 \mathrm{pH}$ unit) was assessed after 5 days of incubation on LB agar. Growth on nutrient agar, trypticase soy agar (TSA; Difco), R2A agar (Difco) and LB agar (Difco) was also evaluated at $30{ }^{\circ} \mathrm{C}$. Salt tolerance was tested in $\mathrm{LN}$ medium (LB without $\mathrm{NaCl}$ ) supplemented with $0-5 \%(\mathrm{w} / \mathrm{v}) \mathrm{NaCl}$ after 10 days of incubation. Biodegradation of chlorothalonil was tested according to the method described by Zhang et al. (2007). All these physiological and biochemical tests were performed together with the reference strain, Lysobacter daejeonensis DSM $17634^{\mathrm{T}}$, which was obtained from the Deutsche Sammlung von Mikroorganismen und Zellkulturen (Braunschweig, Germany).

Polar lipid and quinone analyses of strain $\mathrm{CTN}-1^{\mathrm{T}}$ were carried out by the Identification Service of the DSMZ as described by Tindall (1990a, b). The cellular fatty acid profiles of strain CTN-1 ${ }^{\mathrm{T}}$ and L. daejeonensis DSM $17634^{\mathrm{T}}$ were analysed by the China Center of Industrial Culture Collection by using a gas chromatograph, and both of these strains were cultured in R2A agar in flasks on a rotary shaker (shaking at 160 r.p.m.) at $30{ }^{\circ} \mathrm{C}$ for 48 h. The $\mathrm{G}+\mathrm{C}$ content of the genomic DNA was determined by thermal denaturation (Mandel \& Marmur, 1968), for which Escherichia coli K-12 was used as a standard. Genomic DNA from strain $\mathrm{CTN}-1^{\mathrm{T}}$ was extracted and purified according to standard procedures (Sambrook \& Russell, 2001). The $16 \mathrm{~S}$ rRNA gene cloned into pMD-18T (Takara) was sequenced by using an automated sequencer (Applied Biosystems model 3730). The 16S rRNA gene sequence of strain $\mathrm{CTN}-1^{\mathrm{T}}$ was compared with known sequences found in the GenBank database by using the BLAST program (http://blast.ncbi.nlm.nih.gov/Blast.cgi) and also identified in the EzTaxon server 2.1 (http://147.47.212.35:8080/; Chun et al., 2007). Alignment of the $16 \mathrm{~S}$ rRNA gene sequence of strain $\mathrm{CTN}-1^{\mathrm{T}}$ and of the type strains of recognized Lysobacter species was computed by using the CLUSTAL X program (Thompson et al., 1997), and phylogenetic analysis was performed by using MEGA 3.1 (Kumar et al., 2004). An evolutionary distance matrix was calculated by using the Kimura two-parameter distance model (Kimura, 1980), and a phylogenetic tree was reconstructed with the neighbour-joining method; the robustness of the tree was examined by bootstrap analysis of 1000 replicates (Felsenstein, 1985). DNA-DNA hybridization was performed fluorometrically, according to the method developed by Ezaki et al. (1989), by using photobiotin-labelled DNA probes and microdilution wells. Hybridization was conducted in five replications for each sample. The highest and lowest values obtained for each sample were excluded, and the remaining three values were utilized in the calculation of hybridization values. Levels of DNA-DNA relatedness are given as means \pm SD.

Cells of strain $\mathrm{CTN}-1^{\mathrm{T}}$ were Gram-negative, non-sporeforming, non-motile (but showing gliding activity), aerobic rods $0.5-0.6 \mu \mathrm{m}$ wide and $1.1-1.2 \mu \mathrm{m}$ long (see Supplementary Fig. S1 in IJSEM Online). Strain CTN-1 ${ }^{\mathrm{T}}$ grew well on nutrient agar, TSA, R2A agar and LB agar. Colonies of strain $\mathrm{CTN}^{-{ }^{\mathrm{T}}}$ on $\mathrm{LB}$ agar were circular, smooth with entire margins, non-transparent and pale yellow after 3 days of incubation at $30{ }^{\circ} \mathrm{C}$ (Supplementary Fig. S2). Growth of strain CTN-1 $1^{\mathrm{T}}$ occurred in LN medium with $0-1 \%(\mathrm{w} / \mathrm{v}) \mathrm{NaCl}$; no growth occurred in the presence of $2.0 \%(\mathrm{w} / \mathrm{v}) \mathrm{NaCl}$. Strain $\mathrm{CTN}-1^{\mathrm{T}}$ grew at $15-$ $37{ }^{\circ} \mathrm{C}$ (optimal $28-30{ }^{\circ} \mathrm{C}$ ) and at pH 6.0-9.0 (optimum $\mathrm{pH}$ 7.0-7.5). Strain $\mathrm{CTN}^{\mathrm{T}}{ }^{\mathrm{T}}$ was capable of degrading $20 \mathrm{mg}$ chlorothalonil $\mathrm{l}^{-1}$ to a non-detectable level within $24 \mathrm{~h}$ in liquid culture. However, L. daejeonensis DSM $17634^{\mathrm{T}}$ and Lysobacter niastensis DSM $18481^{\mathrm{T}}$ did not show chlorothalonil-degrading ability. In the API 20NE and API ID 32 GN kits, strain $\mathrm{CTN}-1^{\mathrm{T}}$ assimilated $N$-acetylglucosamine, inositol, suberic acid, potassium 5-ketogluconate, glycogen, 3-hydroxybenzoic acid, L-serine, D-glucose, 
Table 1. Differential phenotypic and biomedical characteristics between strain CTN-1 ${ }^{\top}$ and the type strains of recognized $L y s o b a c t e r$ species

Strains: 1, CTN-1 ${ }^{\mathrm{T}}$ (data from this study); 2, L. daejeonensis DSM $17634^{\mathrm{T}}$ (data from this study); 3, L. soli DCY21 ${ }^{\mathrm{T}}$ (Srinivasan et al., 2010); 4, L. concretionis Ko0 $7^{\mathrm{T}}$ (Weon et al., 2007); 5, L. gummosus LMG 8763 ${ }^{\mathrm{T}}$ (Weon et al., 2007; Ten et al., 2009); 6, L. niastensis DSM 18481 ${ }^{\mathrm{T}}$ (Weon et al., 2007; Ten et al., 2009); 7, L. antibioticus DSM 2044 (Bae et al., 2005; Ten et al., 2009; Wang et al., 2009); 8, L. capsici KCTC 22007 (Park et al., 2008; Ten et al., 2009; Wang et al., 2009); 9, L. defluvii DSM 18482 ${ }^{\mathrm{T}}$ (Yassin et al., 2007; Ten et al., 2009; Wang et al., 2009); 10, L. spongiicola JCM 14760 (Romanenko et al., 2008; Ten et al., 2009; Wang et al., 2009); 11, L. enzymogenes DSM 2043 ${ }^{\mathrm{T}}$ (Bae et al., 2005; Ten et al., 2009; Wang et al., 2009); 12, L. brunescens DSM 6979 ${ }^{\mathrm{T}}$ (Bae et al., 2005; Ten et al., 2009; Wang et al., 2009); 13, L. oryzae DSM 21044 (Aslam et al., 2009); 14, L. yangpyeongensis KACC 11407 ${ }^{\mathrm{T}}$ (Aslam et al., 2009; Ten et al., 2009; Wang et al., 2009); 15, L. niabensis DSM 18244 ${ }^{\mathrm{T}}$ (Weon et al., 2007; Ten et al., 2009; Wang et al., 2009); 16, L. ximonensis NRRL B-51263 ${ }^{\mathrm{T}}$ (Wang et al., 2009); 17, L. koreensis KCTC 12204 ${ }^{\mathrm{T}}$ (Lee et al., 2006; Ten et al., 2009); 18, L. panaciterrae DSM $17927^{\mathrm{T}}$ (Ten et al., 2009; Wang et al., 2009). +, Positive; -, negative; W, weakly positive; ND, no data available.

\begin{tabular}{|c|c|c|c|c|c|c|c|c|c|c|c|c|c|c|c|c|c|c|}
\hline Characteristic & 1 & 2 & 3 & 4 & 5 & 6 & 7 & 8 & 9 & 10 & 11 & 12 & 13 & 14 & 15 & 16 & 17 & 18 \\
\hline \multicolumn{19}{|l|}{ Cell size $(\mu \mathrm{m})$} \\
\hline Width & $0.5-0.6$ & $0.4-0.6$ & $0.2-0.5$ & $0.7-1.0$ & 0.4 & $0.5-0.6$ & 0.4 & $0.3-0.5$ & $\mathrm{ND}$ & $0.5-0.6$ & 0.5 & 0.3 & $0.3-0.5$ & $0.4-0.6$ & 0.5 & 0.5 & $0.5-0.8$ & 1.5 \\
\hline Length & $1.1-1.2$ & $3.0-4.0$ & $0.6-0.9$ & $1.0-13.0$ & 2.0 & $2.0-4.0$ & 6.5 & $2.0-20.0$ & $1.0-2.0$ & $1.3-1.5$ & 38.0 & 11.0 & $1.8-2.0$ & $3.0-4.0$ & $2.0-5.0$ & $1.0-3.0$ & $1.5-2.0$ & 3.0 \\
\hline Nitrate reduction to nitrite & + & + & + & - & - & + & + & - & - & - & - & - & - & - & - & - & - & - \\
\hline Gliding motility & + & - & + & + & + & + & + & + & $\mathrm{ND}$ & - & + & + & + & - & - & + & $\mathrm{ND}$ & + \\
\hline Growth at $5{ }^{\circ} \mathrm{C}$ & - & - & + & + & - & $\mathrm{ND}$ & + & - & - & + & + & + & - & - & + & - & - & - \\
\hline Growth at $\mathrm{pH} 4$ & - & - & + & - & + & + & - & - & $\mathrm{ND}$ & - & $+1-$ & & - & - & - & - & $\mathrm{ND}$ & - \\
\hline Metabolism $\dagger$ & $\mathrm{A}$ & A & $\mathrm{A}$ & A & $\mathrm{F}$ & $\mathrm{F}$ & $\mathrm{F}$ & $\mathrm{F}$ & ND & A & $\mathrm{F}$ & ND & $\mathrm{F}$ & $\mathrm{A}$ & A & A & A & A \\
\hline Chlorothalonil degradation & + & - & $\mathrm{ND}$ & $\mathrm{ND}$ & $\mathrm{ND}$ & - & ND & $\mathrm{ND}$ & $\mathrm{ND}$ & $\mathrm{ND}$ & $\mathrm{ND}$ & $\mathrm{ND}$ & $\mathrm{ND}$ & $\mathrm{ND}$ & $\mathrm{ND}$ & $\mathrm{ND}$ & $\mathrm{ND}$ & $\mathrm{ND}$ \\
\hline Catalase & + & - & + & + & + & + & + & + & + & + & + & + & + & - & + & + & + & - \\
\hline Oxidase & + & + & + & + & + & + & + & + & + & + & + & + & + & - & + & - & + & - \\
\hline \multicolumn{19}{|l|}{ API 20NE results } \\
\hline$\beta$-Galactosidase & - & - & - & - & + & + & + & - & - & - & + & - & $\mathrm{ND}$ & - & - & + & - & - \\
\hline Arginine dihydrolase & + & - & $\mathrm{ND}$ & - & - & - & - & $\mathrm{ND}$ & - & - & - & + & $\mathrm{ND}$ & - & - & - & - & - \\
\hline $\begin{array}{l}N \text {-Acetyl- } \beta \text { - } \\
\text { glucosaminidase }\end{array}$ & - & + & + & - & + & - & - & - & - & - & - & - & ND & + & + & + & - & $\mathrm{ND}$ \\
\hline$\alpha$-Galactosidase & - & + & - & - & - & - & - & + & - & - & - & - & - & - & - & - & - & $\mathrm{ND}$ \\
\hline$\alpha$-Glucosidase & - & + & + & - & - & - & - & + & + & - & + & + & + & + & + & + & - & $\mathrm{ND}$ \\
\hline$\beta$-Galactosidase (PNPG) & - & + & - & - & - & - & + & - & + & - & + & + & - & - & - & + & - & - \\
\hline$\beta$-Glucosidase & - & + & + & - & - & $\mathrm{w}$ & + & + & - & - & + & + & + & - & - & - & - & $\mathrm{ND}$ \\
\hline Trypsin & + & - & - & ND & + & + & - & + & ND & - & + & ND & + & + & - & ND & - & ND \\
\hline DNA G $+C$ content $(\mathrm{mol} \%)$ & 67.1 & 61.7 & 65.4 & 63.8 & 65.7 & 66.6 & 69.2 & 65.4 & 67.1 & 69.0 & 69.0 & 67.7 & 67.4 & 67.3 & 62.5 & 63.5 & 68.9 & 67.0 \\
\hline
\end{tabular}

${ }^{*} \mathrm{C}$, Cream; M, mucoid; DY, deep yellow; LB, light beige; PY, pale yellow; Y, yellow; YC, yellow-cream; BY, brownish yellow.

$\dagger \mathrm{A}$, Aerobic; F, facultatively anaerobic.

‡Data from this study. 
potassium 2-ketogluconate, 3-hydroxybutyric acid, 4hydroxybenzoic acid and L-proline. Differential phenotypic and biomedical characteristics between strain $\mathrm{CTN}-1^{\mathrm{T}}$ and the type strains of recognized Lysobacter species are summarized in Table 1.

The major cellular fatty acids of strain $\mathrm{CTN}-1^{\mathrm{T}}$ were iso$\mathrm{C}_{16: 0}(23.0 \%)$, iso- $\mathrm{C}_{15: 0}(21.4 \%)$ and iso- $\mathrm{C}_{17: 1} \omega 9 c$ $(15.3 \%)$. Minor amounts of $\mathrm{C}_{16: 1} \omega 7 c / \mathrm{C}_{16: 1} \omega 6 c(4.5 \%)$, iso- $\mathrm{C}_{15: 1} \mathrm{~F}(4.4 \%)$, iso- $\mathrm{C}_{11: 0} 3-\mathrm{OH}(3.9 \%)$, iso- $\mathrm{C}_{11: 0}$ $(3.9 \%)$ and iso- $\mathrm{C}_{17: 0}(3.5 \%)$ were also found. The detailed fatty acid profile of strain CTN-1 ${ }^{\mathrm{T}}$ is compared with those of the type strains of recognized Lysobacter species in Supplementary Table S1. The presence of branched fatty acids, namely iso- $\mathrm{C}_{16: 0}$, iso- $\mathrm{C}_{15: 0}$, iso- $\mathrm{C}_{17: 1} \omega 9 \mathrm{c}$ and iso$\mathrm{C}_{17: 0}$, was consistent with the placement of strain $\mathrm{CTN}-1^{\mathrm{T}}$ within the genus Lysobacter (Bae et al., 2005; Weon et al., 2006, 2007; Romanenko et al., 2008). However, differences in the fatty acid profiles were noted. The major quinone detected in strain CTN-1 ${ }^{\mathrm{T}}$ was Q-8 (99\%); Q-7 (1\%) was detected as a minor component. This quinone system is a characteristic feature of the genus Lysobacter (Bae et al., 2005). Strain $C T N-1^{T}$ contained diphosphatidylglycerol, phosphatidylethanolamine and phosphatidylglycerol as major polar lipids, as with recognized species of the genus Lysobacter. However, a minor amount of phosphoaminolipid instead of phosphatidyl- $N$-methylethanolamine was found for strain CTN $-1^{\mathrm{T}}$ (Supplementary Fig. S3), which might differ between species in the genus (Park et al., 2008). The DNA G $+\mathrm{C}$ content of strain $C T N-1^{T}$ was $67.1 \mathrm{~mol} \%$. This value is within the range reported for the genus Lysobacter (Christensen \& Cook, 1978; Aslam et al., 2009).

An almost-complete 16S rRNA gene sequence of strain CTN $-1^{\mathrm{T}}$ consisting of $1504 \mathrm{bp}$ was obtained. The phylogenetic tree shows that strain $\mathrm{CTN}-1^{\mathrm{T}}$ clusters within the genus Lysobacter in the class Gammaproteobacteria (Fig. 1). $16 \mathrm{~S}$ rRNA gene sequence analysis revealed that strain CTN $-1^{\mathrm{T}}$ was related most closely to $L$. daejeonensis DSM $17634^{\mathrm{T}}$ (97.1\% similarity), Lysobacter soli DCY21 ${ }^{\mathrm{T}}(95.7 \%)$, Lysobacter concretionis $\mathrm{Ko}^{\mathrm{T}} 7^{\mathrm{T}}$ (95.5\%), Lysobacter gummosus
LMG $8763^{\mathrm{T}}(95.3 \%)$ and $L$. niastensis DSM $18481^{\mathrm{T}}$ $(95.2 \%)$. Strain $\mathrm{CTN}^{-1}{ }^{\mathrm{T}}$ showed less than $95.0 \% 16 \mathrm{~S}$ rRNA gene sequence similarity to the type strains of other Lysobacter species. Based on the above results, DNA-DNA hybridization experiments were carried out between strain CTN- $1^{\mathrm{T}}$ and $L$. daejeonensis DSM $17634^{\mathrm{T}}$. With labelled total DNA from strain $\mathrm{CTN}-1^{\mathrm{T}}$, the level of DNA-DNA relatedness was $34.6 \pm 3.8 \%$. With labelled DNA from $L$. daejeonensis DSM $17634^{\mathrm{T}}$, the value was $36.1 \pm 2.9 \%$. These values are significantly below the $70 \%$ cut-off proposed by Wayne et al. (1987) for assigning strains to different genomic species.

Strain $\mathrm{CTN}-1^{\mathrm{T}}$ could be distinguished from recognized Lysobacter species based on several phenotypic, biochemical and chemotaxonomic characteristics (Table 1). Notably, strain $\mathrm{CTN}-1^{\mathrm{T}}$ was positive for arginine dihydrolase. Strain $\mathrm{CTN}^{-1}{ }^{\mathrm{T}}$ differed further by its ability to degrade chlorothalonil efficiently. On the basis of the polyphasic taxonomic approach described here, we consider that strain $\mathrm{CTN}-1^{\mathrm{T}}$ represents a novel species of the genus Lysobacter, for which we propose the name Lysobacter ruishenii sp. nov.

\section{Description of Lysobacter ruishenii sp. nov.}

Lysobacter ruishenii (rui.she'ni.i. N.L. gen. n. ruishenii of Rui-Shen, in honour of Rui-Shen Jiao, a respected Chinese microbiologist, for his enormous contributions to the development of microbiology in China).

Cells are Gram-negative, aerobic, non-spore-forming, nonmotile (but show gliding activity) and rod-shaped, about $0.5-0.6 \mu \mathrm{m}$ wide and 1.1-1.2 $\mu \mathrm{m}$ long. Colonies grown on LB agar are convex, circular, smooth, non-transparent and pale yellow after 3 days of incubation at $30{ }^{\circ} \mathrm{C}$. Grows at $15-37{ }^{\circ} \mathrm{C}$ (optimal $28-30{ }^{\circ} \mathrm{C}$ ); no growth occurs below $4{ }^{\circ} \mathrm{C}$ or above $45{ }^{\circ} \mathrm{C}$. The $\mathrm{pH}$ range for growth is $6.0-9.0$ (optimal pH 7.0-7.5). Growth occurs in the absence of $\mathrm{NaCl}$ and no growth occurs in $2.0 \%(\mathrm{w} / \mathrm{v}) \mathrm{NaCl}$. Oxidaseand catalase-positive. Positive for reduction of nitrates to nitrites, but negative for acid production from glucose and

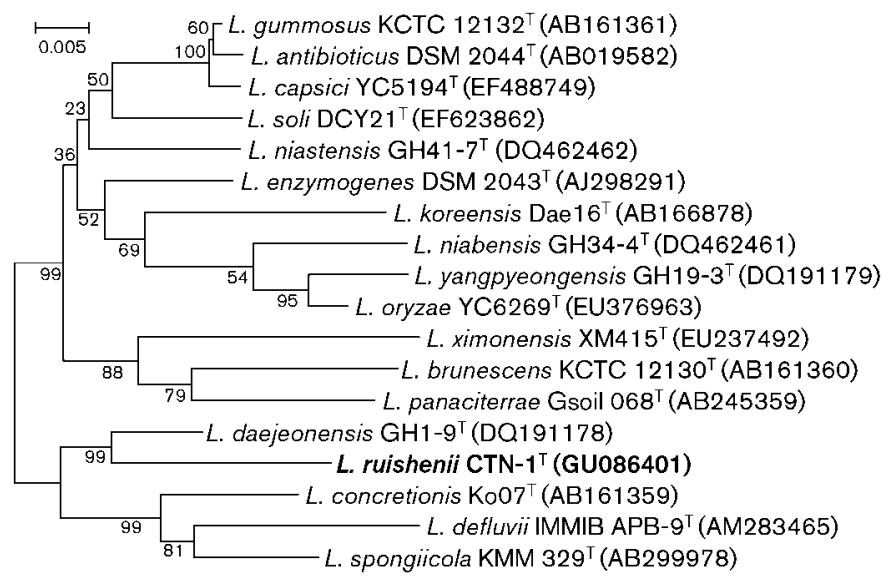

Fig. 1. Phylogenetic tree constructed by the neighbour-joining method based on $16 \mathrm{~S}$ rRNA gene sequences of strain $\mathrm{CTN}-1^{\top}$ and the type strains of recognized Lysobacter species. Bootstrap values expressed as percentages of 1000 replications are given at branch points. Bar, 0.005 substitutions per nucleotide position. 
indole production. Hydrolyses casein, hippurate, aesculin and gelatin, but not elastin, guanine, adenine, cellulose, urea, starch or Tween 20. Utilizes $\mathrm{N}$-acetylglucosamine, inositol, suberic acid, potassium 5-ketogluconate, glycogen, 3-hydroxybenzoic acid, L-serine, D-glucose, potassium 2ketogluconate, 3-hydroxybutyric acid, 4-hydroxybenzoic acid and L-proline, but not maltose or D-mannose. Positive in tests for activities of alkaline phosphatase, esterase (C-4), esterase lipase (C-8), leucine arylamidase, trypsin, acid phosphatase and naphthol-AS-BI-phosphohydrolase, but not for lipase (C-14), valine arylamidase, cystine arylamidase, $\alpha$-chymotrypsin, $\alpha$-galactosidase, $\beta$-galactosidase, $\beta$ glucuronidase, $\alpha$-glucosidase, $\beta$-glucosidase, $N$-acetylglucosaminidase, $\alpha$-mannosidase or $\alpha$-fucosidase. Q- 8 is the major quinone (99\%). The major polar lipids are diphosphatidylglycerol, phosphatidylethanolamine and phosphatidylglycerol. The main cellular fatty acids $(>10 \%)$ are iso$\mathrm{C}_{16: 0}$, iso- $\mathrm{C}_{15: 0}$ and iso- $\mathrm{C}_{17: 1} \omega 9 c$; minor components $(<5 \%)$ include $\mathrm{C}_{16: 1} \omega 7 c / \mathrm{C}_{16: 1} \omega 6 c$, iso- $\mathrm{C}_{15: 1} \mathrm{~F}$, iso- $\mathrm{C}_{11: 0}$ $3-\mathrm{OH}$, iso- $\mathrm{C}_{11: 0}$ and iso- $\mathrm{C}_{17: 0}$. The genomic DNA G+C content of the type strain is $67.1 \mathrm{~mol} \%$.

The type strain, $\mathrm{CTN}_{-1}^{\mathrm{T}}\left(=\mathrm{DSM} 22393^{\mathrm{T}}=\mathrm{CGMCC}\right.$ $1.10136^{\mathrm{T}}$ ), was isolated from a long-term chlorothalonilcontaminated soil at the Jiangyin Suli Chemical Co., Ltd (Jiangsu, China).

\section{Acknowledgements}

We thank Dr B. J. Tindall of the DSMZ for the analysis of respiratory quinones and polar lipids. This work was supported by grants from the National Programs for High Technology Research and Development of China (2007AA10Z405), the Major Projects on Control and Rectification of Water Body Pollution (2009ZX07103002) and the Key Technology R\&D Program of Jiangsu Province (BE2008669).

\section{References}

Ahmed, K., Chohnan, S., Ohashi, H., Hirata, T., Masaki, T. \& Sakiyama, F. (2003). Purification, bacteriolytic activity, and specificity of $\beta$-lytic protease from Lysobacter sp. IB-9374. J Biosci Bioeng 95, $27-34$.

Aslam, Z., Yasir, M., Jeon, C. O. \& Chung, Y. R. (2009). Lysobacter oryzae sp. nov., isolated from the rhizosphere of rice (Oryza sativa L.). Int J Syst Evol Microbiol 59, 675-680.

Atlas, R. M. (1993). Handbook of Microbiological Media. Edited by L. C. Parks. Boca Raton, FL: CRC Press.

Bae, H.-S., Im, W.-T. \& Lee, S.-T. (2005). Lysobacter concretionis sp. nov., isolated from anaerobic granules in an upflow anaerobic sludge blanket reactor. Int J Syst Evol Microbiol 55, 1155-1161.

Brown, A. E. (2007). Benson's Microbiological Applications: Laboratory Manual in General Microbiology. New York: McGraw-Hill.

Buck, J. D. (1982). Nonstaining ( $\mathrm{KOH})$ method for determination of gram reactions of marine bacteria. Appl Environ Microbiol 44, 992993.

Caux, P., Kent, R., Fan, G. \& Stephenson, G. (1996). Environmental fate and effects of chlorothalonil: a Canadian perspective. Crit Rev Environ Sci Technol 26, 45-93.
Christensen, P. \& Cook, F. D. (1978). Lysobacter, a new genus of nonfruiting, gliding bacteria with a high base ratio. Int J Syst Bacteriol 28, 367-393.

Chun, J., Lee, J.-H., Jung, Y., Kim, M., Kim, S., Kim, B. K. \& Lim, Y. W. (2007). EzTaxon: a web-based tool for the identification of prokaryotes based on $16 \mathrm{~S}$ ribosomal RNA gene sequences. Int J Syst Evol Microbiol 57, 2259-2261.

Cox, C. (1997). Chlorothalonil. J Pesticide Reform 17, 14-20.

Ezaki, T., Hashimoto, Y. \& Yabuuchi, E. (1989). Fluorometric deoxyribonucleic acid-deoxyribonucleic acid hybridization in microdilution wells as an alternative to membrane filter hybridization in which radioisotopes are used to determine genetic relatedness among bacterial strains. Int J Syst Bacteriol 39, 224-229.

Felsenstein, J. (1985). Confidence limits on phylogenies: an approach using the bootstrap. Evolution 39, 783-791.

Hashizume, H., Hattori, S., Igarashi, M. \& Akamatsu, Y. (2004). Tripropeptin E, a new tripropeptin group antibiotic produced by Lysobacter sp. BMK333-48F3. J Antibiot (Tokyo) 57, 394-399.

Islam, M. T., Hashidoko, Y., Deora, A., Ito, T. \& Tahara, S. (2005). Suppression of damping-off disease in host plants by the rhizoplane bacterium Lysobacter sp. strain SB-K88 is linked to plant colonization and antibiosis against soilborne peronosporomycetes. Appl Environ Microbiol 71, 3786-3796.

Kazos, E. A., Nanos, C. G., Stalikas, C. D. \& Konidari, C. N. (2008). Simultaneous determination of chlorothalonil and its metabolite 4hydroxychlorothalonil in greenhouse air: dissipation process of chlorothalonil. Chemosphere 72, 1413-1419.

Kimura, M. (1980). A simple method for estimating evolutionary rates of base substitutions through comparative studies of nucleotide sequences. J Mol Evol 16, 111-120.

Kinyon, J. M. \& Harris, D. L. (1979). Treponema innocens, a new species of intestinal bacteria, and emended description of the type strain of Treponema hyodysenteriae Harris et al. Int J Syst Bacteriol 29, 102-109.

Kumar, S., Tamura, K. \& Nei, M. (2004). MEGA3: integrated software for molecular evolutionary genetics analysis and sequence alignment. Brief Bioinform 5, 150-163.

Lee, J. W., Im, W. T., Kim, M. K. \& Yang, D. C. (2006). Lysobacter koreensis sp. nov., isolated from a ginseng field. Int J Syst Evol Microbiol 56, 231-235.

Mandel, M. \& Marmur, J. (1968). Use of ultraviolet absorbancetemperature profile for determining the guanine plus cytosine content of DNA. Methods Enzymol 12B, 195-206.

Ohman, D. E., Cryz, S. J. \& Iglewski, B. H. (1980). Isolation and characterization of Pseudomonas aeruginosa PAO mutant that produces altered elastase. J Bacteriol 142, 836-842.

Park, J. H., Kim, R., Aslam, Z., Jeon, C. O. \& Chung, Y. R. (2008). Lysobacter capsici sp. nov., with antimicrobial activity, isolated from the rhizosphere of pepper, and emended description of the genus Lysobacter. Int J Syst Evol Microbiol 58, 387-392.

Romanenko, L. A., Uchino, M., Tanaka, N., Frolova, G. M. \& Mikhailov, V. V. (2008). Lysobacter spongiicola sp. nov., isolated from a deep-sea sponge. Int J Syst Evol Microbiol 58, 370-374.

Sambrook, J. \& Russell, D. W. (2001). Molecular Cloning: a Laboratory Manual, 3rd edn. Cold Spring Harbor, NY: Cold Spring Harbor Laboratory.

Srinivasan, S., Kim, M. K., Sathiyaraj, G., Kim, H.-B., Kim, Y.-J. \& Yang, D.-C. (2010). Lysobacter soli sp. nov., isolated from soil of a ginseng field. Int J Syst Evol Microbiol 60, 1543-1547.

Ten, L. N., Im, W. T., Kim, M. K., Kang, M. S. \& Lee, S. T. (2004). Development of a plate technique for screening of polysaccharide- 
degrading microorganisms by using a mixture of insoluble chromogenic substrates. J Microbiol Methods 56, 375-382.

Ten, L. N., Jung, H.-M., Im, W.-T., Yoo, S.-A., Oh, H.-M. \& Lee, S.-T. (2009). Lysobacter panaciterrae sp. nov., isolated from soil of a ginseng field. Int J Syst Evol Microbiol 59, 958-963.

Thompson, J. D., Gibson, T. J., Plewniak, F., Jeanmougin, F. \& Higgins, D. G. (1997). The CLUSTAL_X windows interface: flexible strategies for multiple sequence alignment aided by quality analysis tools. Nucleic Acids Res 25, 4876-4882.

Tindall, B. J. (1990a). Lipid composition of Halobacterium lacusprofundi. FEMS Microbiol Lett 66, 199-202.

Tindall, B. J. (1990b). A comparative study of the lipid composition of Halobacterium saccharovorum from various sources. Syst Appl Microbiol 13, 128-130.

Wallace, R. J., Jr, Brown, B. A., Blacklock, Z., Ulrich, R., Jost, K., Brown, J. M., McNeil, M. M., Onyi, G., Steingrube, V. A. \& Gibson, J. (1995). New Nocardia taxon among isolates of Nocardia brasiliensis associated with invasive disease. J Clin Microbiol 33, 1528-1533.

Wang, Y., Dai, J., Zhang, L., Luo, X., Li, Y., Chen, G., Tang, Y., Meng, Y. \& Fang, C. (2009). Lysobacter ximonensis sp. nov., isolated from soil. Int J Syst Evol Microbiol 59, 786-789.
Wayne, L. G., Brenner, D. J., Colwell, R. R., Grimont, P. A. D., Kandler, O., Krichevsky, M. I., Moore, L. H., Moore, W. E. C., Murray, R. G. E. \& other authors (1987). International Committee on Systematic Bacteriology. Report of the ad hoc committee on reconciliation of approaches to bacterial systematics. Int $J$ Syst Bacteriol 37, 463-464.

Weon, H.-Y., Kim, B.-Y., Baek, Y.-K., Yoo, S.-H., Kwon, S.-W., Stackebrandt, E. \& Go, S.-J. (2006). Two novel species, Lysobacter daejeonensis sp. nov. and Lysobacter yangpyeongensis sp. nov., isolated from Korean greenhouse soils. Int J Syst Evol Microbiol 56, 947951.

Weon, H.-Y., Kim, B.-Y., Kim, M.-K., Yoo, S.-H., Kwon, S.-W., Go, S.-J. \& Stackebrandt, E. (2007). Lysobacter niabensis sp. nov. and Lysobacter niastensis sp. nov., isolated from greenhouse soils in Korea. Int J Syst Evol Microbiol 57, 548-551.

Yassin, A. F., Chen, W. M., Hupfer, H., Siering, C., Kroppenstedt, R. M., Arun, A. B., Lai, W. A., Shen, F. T., Rekha, P. D. \& Young, C. C. (2007). Lysobacter defluvii sp. nov., isolated from municipal solid waste. Int J Syst Evol Microbiol 57, 1131-1136.

Zhang, Y., Lu, J., Wu, L., Chang, A. \& Frankenberger, W. T., Jr (2007). Simultaneous removal of chlorothalonil and nitrate by Bacillus cereus strain NS1. Sci Total Environ 382, 383-387. 